\title{
Spór o status archiwów audiowizualnych telewizji publicznej w Polsce
}

Streszczenie: Przedstawiony w tytule niniejszego artykułu problem, budzący do dziś spory interpretacyjne, wymaga analizy z perspektywy różnych aktów normatywnych w kształcie obowiązującym na przestrzeni wskazanego wyżej czasu. W ramach Radiokomitetu w 1987 r. powołano wydzieloną komórkę organizacyjną Państwową Jednostkę Organizacyjną,Polskie Radio i Telewizja”. W takiej sytuacji to Skarb Państwa uważany był w stosunkach cywilno-prawnych za podmiot praw i obowiązków. Skoro p.j.o. PRiTV nie miała statusu odrębnej państwowej osoby prawnej oznaczało to, że mienie tworzone przez tę jednostkę, tzn. składniki materialne, ale także przedmioty prawa autorskich, były własnością Skarbu Państwa, a p.j.o. PRiTV posiadała te zasoby jedynie w zarządzie. W omawianym tu przypadku przedmiotowe mienie, w tym nośniki materialne, na których utrwalono utwory audiowizualne, jak i prawa autorskie i pokrewne do takich utworów, stawały się własnością Skarbu Państwa. Kwestie rozdysponowania majątku po likwidowanej p.j.o PRiTV zostały uregulowane w dwóch odrębnych trybach. Inny przewidziano dla gruntów, budynków i innych urządzeń oraz lokali znajdujących się na gruntach stanowiących własność Skarbu Państwa będących w dniu wejścia w życie ustawy w zarządzie PRiTV, a inny dla pozostałego mienia. W tym pierwszym przypadku składniki te stały się z mocy prawa przedmiotem użytkowania wieczystego utworzonych spółek. Zgodnie z kolei z art. 65 ust. 1 u.r.t.v. ówczesny Minister Finansów został zobowiązany do wniesienia do ww. spółek, mienia pozostałego po likwidacji państwowej jednostki organizacyjnej „Polskie Radio i Telewizja". W momencie tworzenia TVP S.A. majątek likwidowanej jednostki nie został w pełni zinwentaryzowany i wyceniony, co miało późniejszy swój wpływ na przebieg sporu o status archiwów audiowizualnych telewizji publicznej. Kwestia ta m.in. stanowi przedmiot artykułu.

Słowa kluczowe: archiwum audiowizualne TVP, utwór audiowizualny, uprawnienia TVP do materiałów archiwalnych telewizji publicznej

\footnotetext{
O tatus prawny radiofonii i telewizji (w tym radiofonii i telewizji pu-blicznej) w Polsce kształtowany był na przestrzeni lat przez różne akty prawne. U samego zarania radiofonii w dniu 8 kwietnia 1924 r. przyjęto ustawę o poczcie, telegrafie i telefonie (Ustawa, 1924). Na tej pod-
} 
stawie Minister Przemysłu i Handlu w porozumieniu z Ministrem Spraw Wewnętrznych i Ministrem Spraw Wojskowych, w dniu 10 października 1924 r. wydał rozporządzenie dotyczące zasad udzielania zezwoleń na posiadanie i używanie urządzeń radiotechnicznych, określając tym aktem m.in. takie kwestie jak zasady przyznawania zezwoleń na posiadanie i używanie urządzeń odbiorczych, koncesji na zakładanie i eksploatowanie nadawczych stacji radiofonicznych, obowiązku uiszczania opłat abonamentowych oraz warunków produkcji urządzeń radiowych (Miszczak, 1972, s. 34). W dniu 18 sierpnia 1925 r. „Polskie Radio” działające wówczas w formie spółki z ograniczoną odpowiedzialnością, otrzymało koncesję na zasadzie wyłączności na nadawanie programu radiowego na terenie całego kraju na okres 10 lat. $\mathrm{W}$ tym akcie zobowiązano ten podmiot do podjęcia działań polegających na wybudowaniu i uruchomieniu urządzeń radionadawczych w Warszawie (choć tu pierwotnie wykorzystano aparaturę Polskiego Towarzystwa Radiotechnicznego S.A.), a następnie sukcesywnie rozwijaniu działalności nadawczej w innych miastach. Jednocześnie zobowiązano koncesjonariusza do powołania spółki akcyjnej (Statut spółki, 1926) o kapitale 1250000 zł o wartości 100 zł za akcję, przy czym $40 \%$ akcji pozostało w rękach Skarbu Państwa (tytułem aportu wniesiono mienie Państwowej Wytwórni Aparatów Telegraficznych i Telefonicznych o wartości $500000 \mathrm{zł}$ ), a 60\% przeznaczono dla podmiotów prywatnych. W dniu 30 lipca 1929 r. przyznano spółce nową koncesję, tym razem na okres 20 lat. Zgodnie z postanowieniami tego aktu do obowiązków koncesjonariusza należało m.in. tworzenie własnym staraniem i kosztem programu radiofonicznego (Miszczak, 1972, s. 77). W 1935 r. Skarb Państwa uzyskał 95,8\% kapitału zakładowego Spółki, a w 1938 r. posiadał już 97,1\% akcji. Później, z uwagi na wybuch II wojny światowej działalność organizacyjna i nadawcza Polskiego Radia została przerwana.

Jeszcze $\mathrm{w}$ trakcie trwających działań II wojny światowej, w dniu 22 listopada 1944 r. Polski Komitet Wyzwolenia Narodowego wydał dekret (Dekret, 1944) o utworzeniu Przedsiębiorstwa Państwowego „Polskie Radio", stosownie do wcześniejszej ustawy Krajowej Rady Narodowej z 15 sierpnia 1944 r. Przewidziano tu, iż do zadań tej instytucji należało m.in. tworzenie i rozpowszechnianie za pomocą stacji nadawczych materiałów informacyjnych, odczytowych, teatralnych, recytacyjnych, koncertowych (Chałubińska-Jentkiewicz, 2013, s. 21-30). W myśl postanowień art. 5 przywołanego wyżej dekretu, „Polskie Radio” posiadało wówczas osobowość prawną, ale nie podlegało rejestracji sądowej. Majątek tej państwowej osoby prawnej został wówczas wyodrębniony 
z zasobów Skarbu Państwa (Miszczak, 1972, s. 229). Ustawą z dnia 4 lutego 1949 r. utworzono Centralny Urząd Radiofonii (Ustawa, 1949), będący naczelnym organem państwowym w zakresie radiofonii przeznaczonej do powszechnego odbioru. Do kompetencji tego organu należały m.in. kwestie programowe „Polskiego Radia” (Miszczak, 1972, s. 230). Zarządzeniem Prezesa Rady Ministrów utworzono państwowe przedsiębiorstwo „Polskie Radio” oraz kolejnym zarządzeniem dnia 31 grudnia 1949 r. (Zarządzenie, 1949), Państwowe Przedsiębiorstwo Radiofonizacji Kraju.

W okresie od 1951 r. do 1960 r., na mocy dekretu Rady Ministrów z 2 sierpnia 1951 r. (Dekret, 1951) wydanego w porozumieniu z Radą Państwa, funkcjonował Komitet do Spraw Radiofonii „Polskie Radio”, który następnie - na podstawie ustawy z dnia 2 grudnia 1960 r. (Ustawa, 1960) - został przekształcony w Komitet do Spraw Radia i Telewizji „Polskie Radio i Telewizja” zwany powszechnie Radiokomitetem. Był to centralny organ administracji państwowej umiejscowiony przy Radzie Ministrów, do kompetencji którego zaliczono m.in. zarządzanie całością spraw związanych z tworzeniem i emitowaniem programów radiowych i telewizyjnych, a w szczególności „tworzenie i przekazywanie do powszechnego odbioru w kraju i za granicą radiofonicznych i telewizyjnych programów informacyjnych, politycznych, muzycznych, literackich, oświatowych i innych na zasadzie wyłączności [...], popieranie twórczości artystycznej, literackiej i naukowej oraz działalności oświatowej $\mathrm{w}$ dziedzinie radiofonii i telewizji - w porozumieniu z zainteresowanymi ministrami" (Miszczak, 1972, s. 232-233). Ponadto w oparciu o art. 2 tego aktu normatywnego, do zakresu działania Komitetu zaliczono w szczególności: ustalanie - w oparciu o narodowe plany gospodarcze i uchwały Rady Ministrów - wytycznych rozwojowych radiofonii i telewizji dla powszechnego odbioru $\mathrm{w}$ zakresie programowym i organizacyjnym oraz - w porozumieniu z Ministrem Łączności - w zakresie technicznym, tworzenie i przekazywanie do powszechnego odbioru w kraju i za granica radiofonicznych i telewizyjnych audycji (informacyjnych, politycznych, muzycznych, literackich, oświatowych i innych) na zasadach wyłączności, prowadzenie inwestycji w zakresie budowy i rozbudowy na zasadach wyłączności rozgłośni radiofonicznych i telewizyjnych dla powszechnego odbioru, eksploatację na zasadach wyłączności rozgłośni radiofonicznych i telewizyjnych dla powszechnego odbioru, popieranie twórczości artystycznej, literackiej, naukowej i działalności oświatowej w dziedzinie radiofonii i telewizji - $\mathrm{w}$ porozumieniu $\mathrm{z}$ zainteresowanymi ministra- 
mi, prowadzenie międzynarodowej współpracy w dziedzinie radiofonii i telewizji oraz reprezentowanie na terenie międzynarodowym polskiej radiofonii i telewizji, opracowywanie i przedstawianie właściwym organom państwowym wniosków w sprawach planów produkcyjnych odbiorników i technicznych urządzeń nadawczych radiowych i telewizyjnych, organizacji punktów sprzedaży i naprawy odbiorników. Na marginesie warto odnotować, że wcześniej, bo zarządzeniem Przewodniczącego Komitetu do Spraw Radiofonii z dnia 9 czerwca 1960 r. powołano do życia gospodarstwo pomocnicze „Zakład Produkcji Filmów Telewizyjnych”, którego głównym zadaniem była „realizacja materiałów filmowych dla potrzeb programu telewizyjnego typu kronikalnego i ilustracyjnego, dokrętek filmowych, reportaży filmowych oraz produkcji filmów średnioi krótkometrażowych dla potrzeb programu telewizyjnego" (Miszczak, 1972, s. 235).

W ramach Radiokomitetu w 1987 r., na mocy uchwały Rady Ministrów określającej statut tej jednostki, powołano wydzieloną komórkę organizacyjną Państwową Jednostkę Organizacyjną „Polskie Radio i Telewizja" (dalej jako p.j.o. PRiTV), nieposiadającą jednak odrębnej podmiotowości prawnej ani zdolności do czynności prawnych, dysponującą jednak wydzielonym mieniem Skarbu Państwa, przekazanym w zarząd tej jednostki (Kroplewski, 2015, s. 101).

Na mocy ustawy z dnia 29 grudnia 1992 r. o radiofonii i telewizji (Ustawa, 1992) zlikwidowano Komitet do Spraw Radia i Telewizji „Polskie Radio i Telewizja" tworząc spółki publicznej radiofonii (Polskie Radio S.A. oraz 17 regionalnych spółek akcyjnych Polskiego Radia) oraz telewizji (TVP S.A.). Dnia 3 czerwca 1993 r. Przewodniczący Radiokomitetu, wówczas pełniący funkcję kierownika p.j.o. PRiTV w likwidacji, stosownym zarządzeniem utworzył zespół, którego zadaniem miało być opracowanie zasad podziału zbiorów programowych p.j.o. PRiTV. Na zakończenie swojej misji, tj. 30 lipca 1993 r. zespół sporządził protokół datowany na 2 lipca 1993 r. w którym stwierdzono: „Zespół zgromadził informacje o stanie ilościowym lokalizacji, postaciach i zakresie opracowania materiałów programowych zgromadzonych w Warszawie i w terenie oraz sytuacji organizacyjno-strukturalnej zbiorów PRiTV" (Kroplewski, 2015, s. 101). Ustalono, że brak jest podstaw do zastosowania przy podziale zbiorów takich kryteriów jak tytuł własności, poniesione nakładów własnych, postaci materiałów. Zespół rekomendował, aby jako kryterium rozstrzygające przyjąć „kryterium funkcjonalności materiałów według zakresu działania przyszłych spółek i wg producenta programu, 
dla którego materiały zgromadzono" (Kroplewski, 2015, s. 101). Jednocześnie stwierdzono, iż „wniesienie zbiorów w formie aportów wymaga wyceny przed rejestracją spółki. Możliwe jest jednak powiększenie kapitału akcyjnego spółek o zbiory w terminie późniejszym. Wymagałoby to jednak rozstrzygnięcia formy prawnej funkcjonowania zbiorów w okresie po rejestracji spółek do czasu zakończenia wyceny zbiorów" (Kroplewski, 2015, s. 101).

Krajowa Rada Radiofonii i Telewizji w dniu 15 kwietnia 1994 r. zawarła porozumienie z Naczelnym Dyrektorem Archiwów Państwowych w sprawie przekazania jednostkom publicznej radiofonii i telewizji w użyczenie zbiorów dokumentacji byłej państwowej jednostki organizacyjnej „Polskie Radio i Telewizja”. Natomiast w dniu 2 września 1994 r. zawarto umowę pomiędzy TVP S.A. a Archiwum Dokumentacji Mechanicznej, której przedmiotem było użyczenie nośników zawierających audiowizualne materiały archiwalne.

Faktyczna likwidacja Radiokomitetu nastapiła w dniu 9 listopada 1993 r. W dniu 19 listopada 1993 r. sporządzono akt notarialny TVP S.A. i spółka uzyskała osobowość prawną (Kroplewski, 2015, s. 105). W związku z tym należy odnotować, że w $\S 7$ ust. 2 i 3 Statutu TVP S.A. zapisano, iż „do zbiorów programowych telewizji należą również zbiory publicznej radiofonii i telewizji powstałe do dnia 31.12.1993 r., z wyjątkiem zbiorów przekazanych w zarządzanie spółce Polskie Radio S.A. Szczegółowe zasady zarządzania i prowadzenia zbiorów publicznej telewizji określają odrębne przepisy" (Kroplewski, 2015, s. 105).

W dniu 24 maja 1994 r. weszła w życie ustawa z dnia 4 lutego 1994 r. o prawie autorskim i prawach pokrewnych (Ustawa, 1994). Uchylono tym samym ustawę z 10 lipca 1952 r. o prawie autorskim (Ustawa, 1952).

Przedstawiony w tytule niniejszego artykułu problem, wymaga analizy z perspektywy różnych aktów normatywnych w kształcie obowiązującym na przestrzeni wskazanego wyżej czasu. Otóż do wybuchu II wojny światowej, „Polskie Radio” funkcjonowało początkowo jako spółka z ograniczoną odpowiedzialnością, a następnie jako spółka akcyjna, posiadając wówczas odrębną podmiotowość prawną. Później - zgodnie z postanowieniami dekretu z 22 listopada 1944 r. PKWN o utworzeniu Przedsiębiorstwa Państwowego „Polskiego Radio”, Polskie Radio funkcjonowało jako odrębna państwowa osoba prawna, a co z tym się wiąże posiadało osobowość prawna, ale na mocy powyższej regulacji nie podlegało rejestracji sądowej, natomiast majątek tej jednostki został wyodrębniony z zasobów Skarbu Państwa (Miszczak, 1972, s. 229). 
Zmiana nastapiła na podstawie cytowanego powyżej art. 1 ustawy z dnia 2 grudnia 1960 r. (Ustawa, 1960). Wówczas Komitet do Spraw Radia i Telewizji „Polskie Radio i Telewizja” uzyskał status centralnego organu administracji państwowej w sprawach radiofonii i telewizji i podlegał bezpośredniemu nadzorowi Prezesa Rady Ministrów. Na mocy art. 2 tego aktu normatywnego do zakresu działania Komitetu zaliczono m.in.: tworzenie i przekazywanie do powszechnego odbioru w kraju i za granicą radiofonicznych i telewizyjnych programów - informacyjnych, politycznych, muzycznych, literackich, oświatowych i innych - na zasadach wyłączności, popieranie twórczości artystycznej, literackiej, naukowej i działalności oświatowej $\mathrm{w}$ dziedzinie radiofonii i telewizji - w porozumieniu z zainteresowanymi ministrami. W doktrynie podkreśla się, że do zakresu działania tej jednostki ,należało administrowanie całością spraw dotyczących radiofonii i telewizji” (Sobczak, 2001, s. 555). Na szczególną uwagę zasługuje kolejna zmiana w statusie prawnym omawianej tu jednostki, dokonana na mocy uchwały Rady Ministrów z 1987 r. (zmienionej następnie w 1990 r.). Tym aktem bowiem nadano statut Komitetowi. To właśnie w tym dokumencie wyodrębniono w ramach Komitetu, państwową jednostkę organizacyjną „Polskie Radio i Telewizja” (Sobczak, 2001, s. 555).

W tym miejscu należy rozważyć status prawny państwowych jednostek organizacyjnych. Otóż przyjmuje się, że jednostka taka (dotyczy to także p.j.o. PRiTV) nie posiadała odrębnej osobowości prawnej, nie miała również zdolności prawnej i zdolności do czynności prawnych (Wyrok S.A., 2013). Takie stanowisko wynika z wykładni art. 34 k.c. Zgodnie z brzemieniem art. 34 k.c. (Kodeks cywilny, 1964) to Skarb Państwa uważany był (i jest nadal) w stosunkach cywilnoprawnych za podmiot praw i obowiązków, które dotyczą części mienia ogólnonarodowego, niebędących pod zarządem innych państwowych osób prawnych. Oznacza to, że mienie tworzone przez taką jednostkę, tzn. składniki materialne, ale także przedmioty autorskich praw majątkowych, były własnością Skarbu Państwa ex lege, a p.j.o. PRiTV posiadała te zasoby jedynie w zarządzie. Taką wykładnię przywołanych przepisów prawnych zdaje się potwierdzać także judykatura. I tak w wyroku SN z dnia 11 maja 1999 r. przesądzono, że „stosownie do art. 33 i 34 k.c. - Skarb Państwa stanowi jednolity podmiot; niezależnie od wielości wskazanych w pozwie i orzeczeniu sądowym państwowych jednostek organizacyjnych (art. $67 \S 2$ k.p.c.), stroną jest zawsze Skarb Państwa, a nie wskazane jednostki" (Wyrok, 1983). Warto tu także przywołać tezę z wyroku SN z dnia 22 października 
2002 r. (Wyrok SN z 2002), w której zaprezentowano pogląd, że zobowiązania państwowych jednostek organizacyjnych pozostają zobowiązaniami Skarbu Państwa, jako podmiotu prawa wyposażonego w osobowość prawną, który nie uległ likwidacji (art. 33 k.c.). Jak wyżej wskazano p.j.o. PRiTV nie była odrębną państwową osobą prawną. Oznacza to, że w omawianym tu przypadku mienie składające się zarówno z nośników materialnych, jak i dóbr o charakterze niematerialnym stawały się własnością Skarbu Państwa.

$\mathrm{Na}$ podstawie art. 63 ust. 1 ustawy o radiofonii i telewizji (Ustawa, 1992), zlikwidowano Komitet do Spraw Radia i Telewizji „Polskie Radio i Telewizja". Zgodnie z ust. 2 tego przepisu przewidziane w ustawach szczególnych zadania Komitetu oraz Przewodniczącego Komitetu (ale jedynie w zakresie tworzenia i rozpowszechniania programów radiowych i telewizyjnych), na mocy tego przepisu przeszły na jednostki publicznej radiofonii i telewizji, odpowiednio do zakresu ich zadań ustawowych i statutowych. Z kolei w myśl ust. 3 tego przepisu, przewidziane w ustawach szczególnych zadania Komitetu oraz Przewodniczącego Komitetu w zakresie administracji państwowej przeszły do właściwości Krajowej Rady Radiofonii i Telewizji. Jednocześnie w art. 64 u.r.t.v. ustawodawca przesądził, że jednostki publicznej radiofonii i telewizji mogą działać wyłącznie w formie jednoosobowej spółki Skarbu Państwa (Sobczak, 2001, s. 559).

Kompetencję do utworzenia takich podmiotów przepis ten przyznał pierwotnie Ministrowi Finansów, a następnie Ministrowi Skarbu Państwa (w pierwotnym brzmieniu ustawy kompetencję taką posiadał Minister Finansów). Natomiast zgodnie z art. 65 ust. 1 u.r.t.v. także Minister Skarbu Państwa (także w tym przypadku chodziło o Ministra Finansów). Został zobowiązany do wniesienia do ww. spółek, mienia pozostałego po likwidacji państwowej jednostki organizacyjnej „Polskie Radio i Telewizja”. Taki obowiązek zrodził konieczność dokonania szczegółowego zinwentaryzowania majątku pozostałego po likwidowanych jednostkach PRiTV (Sobczak, 2001, s. 561).

W literaturze formułuje się pogląd, że ,przepisy art. 65 u.r.t.v. dotyczą całości mienia (a więc także wartości niematerialnych i prawnych, a w szczególności bardzo istotnych z punktu widzenia mediów - praw autorskich i pokrewnych) pozostałych po likwidacji państwowej jednostki organizacyjnej «Polskie Radio i Telewizja» z wyjątkiem nieruchomości, tj. gruntów, budynków, urządzeń i lokali, których stan prawny został uregulowany w art. 66 u.r.t.v.” (Dziomdziora, 2014, s. 506). Trzeba tu jednak 
wyjaśnić, że o ile druga część tej tezy odnośnie wykładni art. 66 u.r.t.v. nie budzi najmniejszych wątpliwości, o tyle pierwsza część tego poglądu - zważywszy na doświadczenia i rozwój zdarzeń w praktyce - budzi wattpliwości. Przypomnieć tu trzeba, że zgodnie z art. 65 ust. 2 u.r.t.v. Rada Ministrów została zobligowana do określenia w drodze rozporządzenia, szczegółowego trybu inwentaryzacji mienia powstałego po likwidacji tej jednostki, a także zasad podziału i przekazywania tego mienia oraz trybu rozpoznawania spraw spornych. Na podstawie tego upoważnienia ustawowego, Rada Ministrów wydała rozporządzenie w sprawie szczegółowego trybu inwentaryzacji mienia państwowej jednostki organizacyjnej „Polskie Radio i Telewizja”, zasad podziału i przekazywania tego mienia oraz trybu rozpoznawania spraw spornych (Rozporządzenie, 1993). W § 1 pkt 5 tego aktu normatywnego zdefiniowało pojęcie ,zorganizowanej części mienia”. Pod tym pojęciem rozumie się wyodrębnioną organizacyjnie i kadrowo oraz wyposażoną w składniki majątkowe jednostkę PRiTV, zdolną do samodzielnego tworzenia i rozpowszechniania programu radiowego lub telewizyjnego. Na mocy tego aktu wykonawczego Przewodniczący Radiokomitetu w uzgodnieniu z ówczesnym Ministrem Finansów, został zobligowany do wydzielenia zorganizowanych części mienia PRiTV, co miało polegać na podziale lub łączeniu środków pieniężnych, rzeczowych składników majątkowych, wartości niematerialnych i prawnych oraz finansowych składników majątku trwałego i ich przekazaniu samodzielnie bilansującym się jednostkom PRiTV, prowadzącym swoje księgi rachunkowe zgodnie z przepisami ówcześnie obowiązującego rozporządzenia Ministra Finansów w sprawie zasad prowadzenia rachunkowości (Rozporządzenie, 1991). Warto podkreślić, że ów podział lub łączenie mienia miał w świetle powyższej regulacji, obejmować wierzytelności i zobowiązania PRiTV, fundusze wspólne oraz płatności scentralizowane. Rozporządzenie stanowiło także, że wydzielenie zorganizowanych części mienia miało poprzedzać zamknięcie ksiąg rachunkowych i sporządzenie sprawozdań finansowych (bilansów zamknięcia) na dzień likwidacji PRiTV w dotychczasowej strukturze organizacyjnej. Stosownie do treści $\S 3$ ust. 1 tego aktu normatywnego, jednostki PRiTV miały dokonać inwentaryzacji aktywów i pasywów zgodnie z zasadami określonymi w obowiązujących przepisach prawa. Wyjaśniono tu także, że inwentaryzacja aktywów i pasywów, z wyłączeniem środków trwałych, miała być dokonywana na dzień poprzedzający dzień rejestracji spółek. Jednocześnie wyraźnie przewidziano, że inwentaryzacji nie podlegały składniki majątkowe, o których mowa w art. 66 
ust. 1 i 2 u.r.t.v. tj. grunty stanowiące własność Skarbu Państwa, budynki i inne urządzenia oraz lokale znajdujące się na gruntach stanowiących własność Skarbu Państwa, będących w dniu wejścia w życie ustawy w zarządzie PRiTV. Ponadto w rozporządzeniu przewidziano, że spisów z natury składników majątkowych dokonywały komisje inwentaryzacyjne, powołane przez kierowników jednostek, następnie podlegające kontroli biegłych rewidentów. Zgodnie z $§ 4$ ust. 1 jednostki PRiTV zarządzające majątkiem, który ma być wniesiony do spółek, miały dokonać aktualizacji wyceny środków trwałych metodą szczegółową, według stanu na dzień 1 stycznia roku kalendarzowego, w którym nastąpi zarejestrowanie spółek. Na podstawie $\S 5$ ust. 1 rozporządzenia przyznano kierownikom likwidowanych jednostek PRiTV możliwość złożenia odwołania do Komisji Odwoławczej od decyzji Przewodniczącego Radiokomitetu o podziale mienia. W takim przypadku orzeczenia Komisji wydane w tym trybie miały być ostateczne. $\mathrm{W} \S 6$ rozporządzania zobligowano Ministra Finansów, aby po uwzględnieniu dokonanego według powyższych zasad podziału mienia, wniósł do spółek środki pieniężne, rzeczowe składniki majątkowe i co warte podkreślenia w kontekście przedmiotu niniejszej opinii - wartości niematerialne i prawne, wierzytelności oraz finansowe składniki majątku trwałego. W § 7 ust. 1 zobowiązano każdą z jednostek PRiTV do sporządzenia bilansu zamknięcia na dzień poprzedzający rejestrację spółki, następnie podlegającego kontroli biegłych rewidentów i zatwierdzanego przez Ministra Finansów. Takie zatwierdzone dokumenty stawały się bilansami otwarcia utworzonych na mocy u.r.t.v. spółek radiofonii i telewizji publicznej. Co jednak niezwykle istotne z punktu widzenia poruszanej tu problematyki, w świetle analizy zarówno statutu TVP S.A., jak również dokumentacji przygotowanej przez komisję likwidacyjną p.j.o. PRiTV z okresu 1991-1994, należy stwierdzić, że zbiory programowe tej jednostki w momencie likwidacji nie zostały fizycznie zinwentaryzowane, a w konsekwencji nie zostały wniesione w formie aportu do powstających na mocy ustawy spółek publicznej radiofonii i telewizji (Kroplewski, 2015, s. 104). Taka teza znajduje także umocowanie w fakcie, iż na mocy porozumienia Krajowa Rada Radiofonii i Telewizji w dniu 15 kwietnia 1994 r. zawarła porozumienie z Naczelnym Dyrektorem Archiwów Państwowych w sprawie przekazania jednostkom publicznej radiofonii i telewizji w użyczenie zbiorów dokumentacji byłej państwowej jednostki organizacyjnej „Polskie Radio i Telewizja”. Należy podkreślić, że na mocy tego porozumienia w drodze użyczenia przekazano nośniki materialne zawierające materiały archiwalne niezbędne 
do prowadzenia działalności utworzonych spółek publicznej radiofonii i telewizji. Należy jednak wyraźnie podkreślić, że nie doszło w tym przypadku do aportu tych zasobów i to zarówno samych nośników, a tym bardziej praw własności intelektualnej. Stąd też w tym kontekście należy odnotować pogląd zasługujący na uznanie, że „do dnia dzisiejszego udało się uregulować kwestie nośników audiowizualnych znajdujących się w archiwach jednostki organizacyjnej «Polskie Radio i Telewizja». Nie udało się natomiast w pełni rozwiać kwestii własności praw autorskich i pokrewnych" (Dziomdziora, 2014, s. 506). Natomiast nie budzi już żadnych wątpliwości, że treści audiowizualne wytworzone po 1993 r. i prawa autorskie lub pokrewne do nich, a więc już po utworzeniu TVP S.A. jako odrębnej osoby prawnej, stanowią przedmiot wyłącznych majątkowych praw autorskich TVP S.A. jako producenta (lub koproducenta) utworu audiowizualnego (Chałubińska-Jentkiewicz, 2013, s. 43). Powyższa konstatacja dotyczy także materialnych nośników (Chałubińska-Jentkiewicz, 2013, s. 45).

Warto także zwrócić uwagę na postanowienia ustawy (Ustawa, 1983) o narodowym zasobie archiwalnym i archiwach. Zgodnie z nimi narodowy zasób archiwalny służy nauce, kulturze, gospodarce narodowej oraz potrzebom obywateli. Zgodnie z art. 2 ust. 2 tego przepisu narodowy zasób archiwalny, w zależności od stosunku własności materiałów archiwalnych, dzieli się na państwowy oraz niepaństwowy. W art. 1 tego aktu normatywnego zdefiniowano, że materiałami archiwalnymi wchodzącymi do narodowego zasobu archiwalnego, są wszelkiego rodzaju akta i dokumenty, korespondencja, dokumentacja finansowa, techniczna i statystyczna, mapy i plany, fotografie, filmy i mikrofilmy, nagrania dźwiękowe i wideofonowe, dokumenty elektroniczne w rozumieniu przepisów ustawy (Ustawa, 2005) o informatyzacji działalności podmiotów realizujących zadania publiczne oraz inna dokumentacja, bez względu na sposób jej wytworzenia, mająca znaczenie jako źródło informacji o wartości historycznej o działalności Państwa Polskiego, jego poszczególnych organów i innych państwowych jednostek organizacyjnych oraz o jego stosunkach z innymi państwami, o rozwoju życia społecznego i gospodarczego, o działalności organizacji o charakterze politycznym, społecznym i gospodarczym, zawodowym i wyznaniowym, o organizacji i rozwoju nauki, kultury i sztuki, a także o działalności jednostek samorządu terytorialnego i innych samorządowych jednostek organizacyjnych - powstała w przeszłości i powstająca współcześnie. Co warte podkreślenia - zgodnie z art. 3 tej ustawy - materiały archiwalne stanowiące narodowy 
zasób archiwalny przechowuje się wieczyście. Należy jednak podkreślić, iż w takim przypadku chodzi zawsze o tzw. corpus mechanicum (nośnik) nie zaś o przedmiot prawa autorskiego (Niewęgłowski, 2015, s. 35).

Wreszcie koniecznym wydaje się odniesienie do kwestii statusu prawnoautorskiego spornych materiałów. Na wstępie należy wyjaśnić, że ustawa z 10 lipca 1952 r. o prawie autorskim (Ustawa, 1952) nie znała kategorii „utwór audiowizualny”, nie posługiwała się nawet nim (Grzybowski, 2003, s. 5). Używała natomiast takich kategorii jak film kinematograficzny, utwór sztuki kinematograficznej, utwór kinematograficzny. Żadnego z powyższych pojęć jednak nie definiowała. W myśl postanowień art. 1 $\S 1$ tego aktu normatywnego, przedmiotem prawa autorskiego był każdy utwór literacki, naukowy i artystyczny, ustalony w jakiejkolwiek postaci. $\mathrm{W} \S 2$ tego przepisu stanowiono dodatkowo, iż przedmiotem prawa autorskiego są m.in. utwory sztuki kinematograficznej, utrwalone w scenariuszach, rysunkach lub fotografiach. Z kolei w art. 13 tego aktu normatywnego użyto terminu ,film kinematograficzny”. Zgodnie z tym przepisem prawo autorskie do tej kategorii służyło przedsiębiorstwu, które wytworzyło film (Uchwała 7 sędziów SN 1968; Wyrok SN, 2004; Wyrok S.A., 1992). W doktrynie przeważa pogląd formułowany w oparciu o postanowienia Konwencji berneńskiej, o konieczności szerokiego rozumienia tego pojęcia, w znaczeniu zbliżonym do terminu występującego w ustawie z 1994 r., a mianowicie utworu audiowizualnego (Śęzak, 2011, s. 10-11; Czajkowska-Dąbrowska, 2011, s. 420; Barta, Markiewicz, 2003, s. 30; Nowicka, 2013, s. 121-128), także nie zdefiniowanego (Gienias, 2014, s. 458; Bukowski, 2014, s. 916-917). Aczkolwiek nie całkowicie tożsamym. Można zgodzić się bowiem z poglądem, że ,[...] nie każda audycja telewizyjna, nawet spełniająca przesłanki utworu, powinna być kwalifikowana tylko z powodu jej wzrokowo-słuchowej percepcji jako utwór audiowizualny. Istnieje przecież wiele gatunków twórczości telewizyjnej - np. formy publicystyczne - do których reżym odnoszący się do utworów audiowizualnych jest zdecydowanie nieadekwatny, najczęściej ze względu na brak w nich pierwiastka współtwórczości” (Gienias, 2014, s. 420-421). Z kolei w pierwotnym brzmieniu ustawy z 1994 r. o prawie autorskim i prawach pokrewnych, wprowadzono do porządku prawnego pojęcie ,utworu audiowizualnego (w tym audialnego)", a po nowelizacji z 2002 r. „utworu audiowizualnego (w tym filmowego)” (Barta, Markiewicz, Matlak, 2003, s. 37). Zgodnie z art. 69 pr. aut. ustalono, że utwór audiowizualny jest utworem współautorskim (Sokołowska, 2011, s. 59 i n.), co oznacza, iż po pierwsze, stosuje się reguły okre- 
ślone w art. 9 pr. aut. określające zasady współtwórczości, a po drugie, utwór taki powstaje w sposób pierwotny na rzecz współautorów (Bukowski, 2015, s. 150). Zgodnie z tym przepisem współtwórcami utworu audiowizualnego są osoby, które wniosły wkład twórczy w jego powstanie, a w szczególności: reżyser, operator obrazu, twórca adaptacji utworu literackiego, twórca stworzonych dla utworu audiowizualnego utworów muzycznych lub słowno-muzycznych oraz twórca scenariusza. Przepis ten w pierwotnym brzmieniu nie wymieniał w katalogu współtwórców operatora obrazu. Zmiana została wprowadzona na mocy art. nowelizacji tej ustawy z dnia 9 czerwca 2000 r. (Gromotowicz, 2011, s. 49 i n.; Sieńczyło-Chlabicz, Banasiuk, 2011, s. 75 i n.). Trzeba jednak dodać, że w art. 70 tego aktu normatywnego zamieszczono domniemanie, że producent utworu audiowizualnego nabywa na mocy umowy o stworzenie utworu albo umowy o wykorzystanie już istniejącego utworu wyłączne prawa majątkowe do eksploatacji tych utworów w ramach utworu audiowizualnego jako całości (Wyrok S.A., 2003; Czajkowska-Dąbrowska, 2011, s. 426-427; Gienias, 2014, s. 466-467). Trzeba tu dodać, że brzmienie tego przepisu na przestrzeni czasu także ewoluowało. Zgodnie z pierwotnym brzmieniem tego przepisu, autorskie prawa majątkowe do utworu audiowizualnego przysługiwały producentowi, a jednocześnie wyraźnie tu przesądzono, że prawa twórców utworów mających samodzielne znaczenie nie mogą być wykonywane $\mathrm{z}$ uszczerbkiem dla producenta lub pozostałych twórców. Zgodnie z nowelizacją z 2000 r. (Ustawa, 2000) $\mathrm{w}$ art. 70. ust. 1 zamieszczono domniemanie, że producent utworu audiowizualnego nabywa na mocy umowy o stworzenie utworu albo umowy o wykorzystanie już istniejącego utworu wyłączne prawa majątkowe do eksploatacji tych utworów w ramach utworu audiowizualnego jako całości. Natomiast w ust. 2 przesądzono, że główny reżyser, operator obrazu, twórcy scenariusza, twórcy innych utworów literackich lub muzycznych, które stworzone zostały do utworu audiowizualnego lub w nim wykorzystane, oraz artyści wykonawcy są uprawnieni do: 1) wynagrodzenia proporcjonalnego do wpływów z tytułu wyświetlania utworu audiowizualnego w kinach; 2) stosownego wynagrodzenia z tytułu najmu egzemplarzy utworów audiowizualnych i ich publicznego odtwarzania; 3) stosownego wynagrodzenia $\mathrm{z}$ tytułu nadawania utworu $\mathrm{w}$ telewizji lub poprzez inne środki publicznego udostępniania utworów; 4) stosownego wynagrodzenia $\mathrm{z}$ tytułu reprodukowania utworu audiowizualnego na egzemplarzu przeznaczonym do własnego użytku osobistego. Ust. 2 tego przepisu został wykreślony w 2007 roku, a jednocześnie w tym samym roku dodano 
ust. $2^{1}$, zgodnie z którym Współtwórcy utworu audiowizualnego oraz artyści wykonawcy są uprawnieni do: 1) wynagrodzenia proporcjonalnego do wpływów z tytułu wyświetlania utworu audiowizualnego w kinach; 2) stosownego wynagrodzenia $z$ tytułu najmu egzemplarzy utworów audiowizualnych i ich publicznego odtwarzania; 3) stosownego wynagrodzenia $\mathrm{z}$ tytułu nadawania utworu $\mathrm{w}$ telewizji lub poprzez inne środki publicznego udostępniania utworów; 4) stosownego wynagrodzenia z tytułu reprodukowania utworu audiowizualnego na egzemplarzu przeznaczonym do własnego użytku osobistego (Błeszyński, 2011, s. 43). W tym kontekście warto tu przypomnieć, że zgodnie z art. 27 pkt 2 ustawy o prawie autorskim z 1952 r., autorskie prawa majątkowe do utworu kinematograficznego, wygasały z upływem lat dziesięciu od pierwszego publicznego wykonania. $\mathrm{W}$ art. 36 ustawy o prawie autorskim $i$ prawach pokrewnych z 1994 r. w pierwotnym brzmieniu przewidziano, że autorskie prawa majątkowe gasną z upływem lat pięćdziesięciu od pierwszej publikacji, jeżeli z mocy ustawy autorskie prawa majątkowe przysługują innej osobie niż twórca. Z kolei przepis ten w brzmieniu nadanym przez ustawę z dnia 9 czerwca 2000 r. o zmianie ustawy o prawie autorskim i prawach pokrewnych (Ustawa, 2000), okres ochrony przedłużył do lat siedemdziesięciu w odniesieniu do utworu audiowizualnego - od śmierci najpóźniej zmarłej z wymienionych osób: głównego reżysera, autora scenariusza, autora dialogów, kompozytora muzyki skomponowanej do utworu audiowizualnego. Należy tu przypomnieć dodatkowo, że p.a.p.p. w art. 124 przewidziały dość skomplikowane wytyczne dotyczące zakresu przedmiotowego stosowania postanowień tego aktu normatywnego. I tak po pierwsze - co oczywiste - przepisy ustawy stosuje się do utworów ustalonych po raz pierwszy po jej wejściu w życie. Po drugie, także do tych utworów których prawa autorskie według przepisów dotychczasowych nie wygasły. Wreszcie ustawa przewiduje także możliwość „odżycia” ochrony. Otóż zgodnie z art. 124 ust. 1 pkt 3 p.a.p.p. postanowienia ustawy stosuje się także do utworów, do których prawa autorskie według przepisów dotychczasowych wygasły, a które według niniejszej ustawy korzystają nadal z ochrony. Ta ostatnia reguła nie dotyczy jednak okresu między wygaśnięciem ochrony według ustawy dotychczasowej i wejściem w życie niniejszej ustawy. Dominuje pogląd, iż wydłużony okres ochrony praw majątkowych stosuje się zarówno do tych utworów, których ochrona wygasła jeszcze przed wejściem ustawy z 1994 r., jak i tych, które weszły do domeny publicznej już po 1994, ale jeszcze przed nowelizacją z 2000 r. (Targosz, 2015, s. 1502-1503; Sarbiński, 2005, 
s. 223 i n.). Innymi słowy, mimo wygaśnięcia autorskich praw majątkowych, zgodnie z uchylonymi przepisami, okres ochrony trwać będzie „od daty wejścia ustawy do czasu upłynięcia okresu obliczanego według zasad podanych w art. 36-40" (Barta, Markiewicz, 2011, s. 794; Tomczyk, 2014, s. 882-883). Warto tu poruszyć jeszcze jedną kwestię, a mianowicie zakresu podmiotowego praw autorskich wobec utworów audiowizualnych w kontekście „odżycia” praw autorskich w związku z wydłużeniem ich ochrony do 70 lat, a więc rozstrzygnięcia kwestii na rzecz kogo prawa takie odżywają. Spotkać można w literaturze kilka odmiennych koncepcji. Według jednego ze stanowisk, odżycie tych praw następuje na rzecz podmiotów, którym przysługiwały w momencie ich wygaśnięcia (Mioduszewski, 2012, s. 44). Według innego poglądu odżycie następuje nie tylko na rzecz podmiotów, którym przysługiwały ex lege, ale także tych, którzy uzyskali je na podstawie czynności prawnej (Traple, 2013, s. 250). Podzielić należy pogląd, iż ,przyjmując, że nabycie praw autorskich przez producenta $\mathrm{w}$ ramach konstrukcji nabycia ex lege obejmowało wszystkie pola eksploatacji audiowizualnej utworu audiowizualnego, należy uznać, że po stronie współtwórców odżyły tylko prawa do wykorzystywania utworu wkładowego co do eksploatacji poza dziełem audiowizualnym" (Traple, 2000, passim).

Podsumowując należy stwierdzić, iż po pierwsze, od 1951 r. do 1960 r., funkcjonował Komitet do Spraw Radiofonii „Polskie Radio”, który został przekształcony w 1960 r. w Komitet do Spraw Radia i Telewizji „Polskie Radio i Telewizja" (Radiokomitet). W ramach Radiokomitetu w 1987 r. powołano wydzieloną komórkę organizacyjną Państwową Jednostkę Organizacyjna „Polskie Radio i Telewizja”. Państwowa jednostka organizacyjna „Polskie Radio i Telewizja” nie posiadała odrębnej osobowości prawnej, nie miała również zdolności prawnej i zdolności do czynności prawnych. W takiej sytuacji to Skarb Państwa uważany był w stosunkach cywilnoprawnych za podmiot praw i obowiązków. Skoro p.j.o. PRiTV nie miała statusu odrębnej państwowej osoby prawnej oznaczało to, że mienie tworzone przez tę jednostkę, tzn. składniki materialne, ale także przedmioty prawa autorskich, były własnością Skarbu Państwa, a p.j.o. PRiTV posiadała te zasoby jedynie w zarządzie. Po drugie, zgodnie z brzmieniem art. 34 k.c. Skarb Państwa jest w stosunkach cywilnoprawnych podmiotem praw i obowiązków, które dotyczą mienia państwowego, które nie należy do innych państwowych osób prawnych. Jak wyżej wskazano p.j.o. PRiTV nie była odrębną państwową osobą prawną. Oznacza to, że $\mathrm{w}$ omawianym tu przypadku przedmiotowe mienie, w tym nośniki mate- 
rialne, na których utrwalono utwory audiowizualne, jak i prawa autorskie i pokrewne do takich utworów, stawały się własnością Skarbu Państwa. Warto także zwrócić uwagę, że z powyższą konstatacją korespondują postanowienia ustawy z dnia 14 lipca 1983 r. o narodowym zasobie archiwalnym i archiwach oraz porozumienia zawartego w dniu 15 kwietnia 1994 r. przez Krajową Radę Radiofonii i Telewizji z Naczelnym Dyrektorem Archiwów Państwowych w sprawie przekazania jednostkom publicznej radiofonii i telewizji w użyczenie zbiorów dokumentacji byłej państwowej jednostki organizacyjnej „Polskie Radio i Telewizji”. Należy podkreślić, że na mocy tego porozumienia w drodze użyczenia przekazano nośniki materialne zawierające materiały archiwalne niezbędne do prowadzenia działalności utworzonych spółek publicznej radiofonii i telewizji. Nie doszło w tym przypadku na mocy tego porozumienia do aportu tych zasobów i to zarówno samych nośników, a tym bardziej praw własności intelektualnej. Po trzecie, kwestie rozdysponowania majątku po likwidowanej p.j.o. PRiTV zostały uregulowane w dwóch odrębnych trybach. Inny przewidziano dla gruntów, budynków i innych urządzeń oraz lokali znajdujących się na gruntach stanowiących własność Skarbu Państwa będących w dniu wejścia w życie ustawy w zarządzie PRiTV, a inny dla pozostałego mienia. $\mathrm{W}$ tym pierwszym przypadku zgodnie $\mathrm{z}$ art. 66 ust. 1 u.r.t.v. składniki te stały się $\mathrm{z}$ mocy prawa przedmiotem użytkowania wieczystego utworzonych spółek. Zgodnie z kolei z art. 65 ust. 1 u.r.t.v. ówczesny Minister Finansów został zobowiązany do wniesienia do ww. spółek, mienia pozostałego po likwidacji państwowej jednostki organizacyjnej „Polskie Radio i Telewizja”. Taki obowiązek zrodził konieczność dokonania szczegółowego zinwentaryzowania majątku pozostałego po likwidowanych jednostkach PRiTV. W cytowanym rozporządzeniu w sprawie szczegółowego trybu inwentaryzacji mienia państwowej jednostki organizacyjnej „Polskie Radio i Telewizja” (Rozporządzenie, 1993), zasad podziału i przekazywania tego mienia oraz trybu rozpoznawania spraw spornych przesądzono, że inwentaryzacja aktywów i pasywów, z wyłączeniem środków trwałych, miała być dokonywana na dzień poprzedzający dzień rejestracji spółek. W momencie tworzenia TVP S.A. majątek likwidowanej jednostki nie został w pełni zinwentaryzowany i wyceniony. Dotyczy to w szczególności majątkowych praw autorskich do materiałów audiowizualnych wytworzonych przez p.j.o. PRiTV. Stąd też należy przyjąć, że tych składników mienia likwidowanej jednostki nie wniesiono aportem majątkowych praw autorskich do materiałów audiowizualnych wytworzonych przez p.j.o. PRiTV. Nie doszło zatem w tym 
przypadku do aportu tych zasobów do majątku tworzonych spółek. Dlatego też należy przyjąć, że należą one w dalszym ciągu do Skarbu Państwa. Po czwarte, przepisy intertemporalne zamieszczone w p.a.p.p. przewidują skomplikowane wytyczne dotyczące zakresu przedmiotowego stosowania postanowień tego aktu normatywnego. Zgodnie z art. 124 ust. 1 pkt 3 p.a.p.p. postanowienie ustawy stosuje się także do utworów, do których prawa autorskie według przepisów dotychczasowych wygasły, a które według niniejszej ustawy korzystają nadal z ochrony. Wydłużony okres ochrony praw majątkowych stosuje się zarówno do tych utworów, których ochrona wygasła jeszcze przed wejściem ustawy z 1994 r., jak i tych które weszły do domeny publicznej już po 1994, ale jeszcze przed nowelizacją z 2000 r. Odrodzenie tych praw nastąpiło zatem na rzecz Skarbu Państwa. Po piąte, materiały audiowizualne wytworzone po 1993 r., a więc po utworzeniu TVP S.A. stanowią przedmiot wyłącznych majątkowych praw autorskich TVP S.A. jako producenta (lub koproducenta) utworu audiowizualnego.

\section{Bibliografia}

Barta J., Markiewicz R. (2003), Utwór audiowizualny, w: System Prawa Prywatnego, Tom 13, Prawo autorskie, red. J. Barta, 3 wydanie, Warszawa.

Barta J., Markiewicz R. (2011), Komentarz do art. 124, w: Prawo autorskie i prawa pokrewne, red. J. Barta, R. Markiewicz, Warszawa.

Barta J., Markiewicz R., Matlak A. (2013), Utworu audiowizualne, w: System Prawa Prywatnego, t. 13, Prawo autorskie, red. J. Barta, 3 wydanie, Warszawa.

Błeszyński J. (2011), Konstrukcja praw do utworu audiowizualnego, w: Utwór audiowizualny. Zakres pojęcia i ochrony prawnej, red. K. Lewandowski, Poznań.

Bukowski M. (2015), Komentarz do art. 69, w: Prawo autorskie i prawa pokrewne. Komentarz LEX, red. D. Flisak, Warszawa.

Bukowski M. (2015a), Przepisy szczególne dotyczqce utworów audiowizualnych, w: Prawo autorskie i prawa pokrewne. Komentarz LEX, red. D. Flisak, Warszawa.

Chałubińska-Jentkiewicz K. (2013), Problematyka statusu prawnego archiwalnego zasobu audiowizualnego nadawcy publicznego, „Przegląd Prawa Handlowego", $\mathrm{nr} 6$.

Czajkowska-Dąbrowska M. (2011), Komentarz do art. 69, w: Prawo autorskie i prawa pokrewne. Komentarz, red. J. Barta, R. Markowski, Warszawa.

Dekret (1944) z 22 listopada 1944 r. Polski Komitet Wyzwolenia Narodowego, Dz. U. 1944, Nr 13, poz. 69. 
Dekret (1951) Rady Ministrów z 2 sierpnia 1951 r., Dz. U. Nr 41, poz. 308.

Dziomdziora W. (2014), Komentarz do art. 65, w: Ustawa o radiofonii i telewizji. Komentarz, red. S. Piątek, Warszawa.

Gienias K. (2014), Komentarz do art. 69, w: red. Ustawa o prawie autorskim i prawach pokrewnych. Komentarz, E. Ferenc-Szydełko, Warszawa.

Gromotowicz M. (2011), Twórcy utworu audiowizualnego, w: Utwór audiowizualny. Zakres pojęcia i ochrony prawnej, red. K. Lewandowski, Poznań.

Grzybowski S. (2003), Geneza i miejsce prawa autorskiego w systemie prawa, w: System Prawa Prywatnego, t. 13, Prawo autorskie, red. J. Barta, wyd. 1, Warszawa.

Kodeks cywilny, Dz. U. 1964 Nr 16, poz. 93, tj. Dz. U. 2014, poz. 121.

Kroplewski R. (2015), Archiwa audiowizualne telewizji publicznej - od sejfu do kreatywności, „Kwartalnik Antymonopolowy Regulacyjny”, nr 7 (4).

Mioduszewski M. (2012), Majatkowe prawa autorskie do utworów filmowych powstatych przed wejściem $w$ życie ustawy o prawie autorskim i prawach pokrewnych, „Zeszyty Naukowe UJ Prace z Prawa Własności Intelektualnej”, z. 2.

Miszczak S. (1972), Historia radiofonii i telewizji w Polsce, Warszawa.

Niewęgłowski A. (2015), Ochrona niematerialnego dziedzictwa kulturalnego, Warszawa.

Nowicka A. (2013), Utwory audiowizualne, w: System Prawa Prywatnego, t. 13, Prawo autorskie, red. J. Barta, wyd. 3, Warszawa.

Rozporządzenie (1991) Ministra Finansów z dnia 15 stycznia 1991 r. w sprawie zasad prowadzenia rachunkowości, Dz. U. Nr 10, poz. 35 z późn. zm.

Rozporządzenie (1993) Rady Ministrów z dnia 26 marca 1993 r. w sprawie szczegótowego trybu inwentaryzacji mienia państwowej jednostki organizacyjnej ,Polskie Radio i Telewizja”, zasad podziatu i przekazywania tego mienia oraz trybu rozpoznawania spraw spornych, Dz. U. Nr 24, poz. 105.

Sarbiński R. M. (2005), Wybrane problemy intertemporalne prawa autorskiego, ,Zeszyty Naukowe UJ Prace z Prawa Własności Intelektualnej”, z. 89.

Sieńczyło-Chlabicz J., Banasiuk J. (2011), Twórcy dzieł uprzednio stworzonych a współtwórczość utworu, w: Utwór audiowizualny. Zakres pojęcia i ochrony prawnej, red. K. Lewandowski, Poznań.

Sobczak J. (2001), Radiofonia i telewizjia. Komentarz do ustawy, Kraków.

Sokołowska D. (2011), Współtwórczość a utwór audiowizualny, w: Utwór audiowizualny. Zakres pojęcia i ochrony prawnej, red. K. Lewandowski, Poznań.

Statut (1926) spółki Polskie Radio, „Monitor Polski” 1926, Nr 26, poz. 110.

Śęzak P. (2011), Pojęcie utworu audiowizualnego, w: Utwór audiowizualny. Zakres pojęcia i ochrony prawnej, red. K. Lewandowski, Poznań.

Targosz T. (2015), Komentarz do art. 124, w: Prawo autorskie i prawa pokrewne. Komentarz LEX, red. D. Flisak, Warszawa. 
Tomczyk S. (2014), Komentarz do art. 124, w: Ustawa o prawie autorskim i prawach pokrewnych. Komentarz, red. E. Ferenc-Szydełko, Warszawa.

Traple E. (2000), Umowy o eksploatację utworów w prawie polskim, Warszawa.

Traple E. (2013), Autorskie prawa majatkowe, w: System Prawa Prywatnego, t. 13: Prawo autorskie, red. J. Barta, 3 wydanie, Warszawa.

Uchwała 7 sędziów SN - zasada prawna z 19 lutego 1968 r., sygn. akt III CZP 40/67, „OSNC” 1969, z. 4, poz. 59.

Ustawa (1924) z 8 kwietnia 1924 r. o poczcie, telegrafie i telefonie, Dz. U. R.P. 1924, $\mathrm{Nr} 58$, poz. 584.

Ustawa (1926) z dnia 29 marca 1926 r. o prawie autorskim, Dz. U. 1926, Nr 48, poz. 286.

Ustawa (1944) z dnia 4 lutego 1949 r. o utworzeniu i zakresie działania Centralnego Urzędu Radiofonii, Dz. U. 1949, Nr 9, poz. 50,

Ustawa (1952) z 10 lipca 1952 r. o prawie autorskim, Dz. U. 1952, Nr 34, poz. 234 z późn. zm.

Ustawa (1960) z dnia 2 grudnia 1960 r. o Komitecie do Spraw Radia i Telewizji „Polskie Radio i Telewizja”, Dz. U. 1960, Nr 54, poz. 307.

Ustawa (1983) z dnia 14 lipca 1983 r. o narodowym zasobie archiwalnym $i$ archiwach, Dz. U. 2015, poz. 1446.

Ustawa (1992) z dnia 29 grudnia 1992 r. o radiofonii i telewizji, Dz. U. 1993, Nr 7, poz. 34 z późn. zm., tj. Dz. U. 2016, poz. 639.

Ustawa (1994) z dnia 4 lutego 1994 r. o prawie autorskim i prawach pokrewnych, Dz. U. 1994 Nr 24, poz. 83, tj. Dz. U. 2006, Nr 90, poz. 631 z późn. zm.

Ustawa (2000) z dnia 9 czerwca 2000 r. o zmianie ustawy o prawie autorskim i prawach pokrewnych, Dz. U. 2000, Nr 53, poz. 637.

Ustawa (2005) z dnia 17 lutego 2005 r. o informatyzacji działalności podmiotów realizujacych zadania publiczne, Dz. U. 2014, poz. 1114.

Wyrok S.A. (1992) w Warszawie z dnia 17 stycznia 1992 r., sygn. I Acr 296/91, Lex nr 62598.

Wyrok S.A. (2003) w Krakowie z 14 stycznia 2003 r., sygn. I Aca 1137/02, „TPP” 2003, nr 3, s. 117.

Wyrok S.A. (2013) w Lodzi z dnia 29 kwietnia 2013 r., sygn. I ACa 262/13, LEX nr 1314778.

Wyrok SN (1983) z dnia 13.04.1983 r., sygn. IV CR 66/83, „OSCN” 1984, z. 1, poz. 5.

Wyrok SN (1999) z dnia 11 maja 1999 r., sygn. I CKN 1148/97, „OSNC” 1999, z. 12, poz. 205, „Pr.Gosp.” 1999, z. 11, poz. 5, „Biul. SN” 1999, z. 9, poz. 6.

Wyrok SN (2004) z dnia 3 grudnia 2004 r., sygn. I CKN 312/02, LEX nr 1500021.

Zarządzenie (1949) Prezesa Rady Ministrów z dnia 31 grudnia 1949 r. o utworzeniu Państwowego Przedsiębiorstwa Radiofonizacji Kraju, „Monitor Polski” 1950, Nr A-1, poz. 3. 


\title{
Dispute over the status of audiovisual archival materials of the public television in Poland
}

\begin{abstract}
Summary
The issue presented in the title of this paper, which continues to raise interpretational controversies, needs to be analyzed from the point of view of different regulations binding over a given period of time. In 1987, a separate unit - the State Organizational Unit "Polish Radio and Television" - was established as part of the Radio and Television Committee. In these circumstances the State Treasury was deemed to be the holder of rights and responsibilities in legal relations. As the State Organizational Unit "Polish Radio and Television" did not enjoy the status of separate legal entity, the assets generated by this unit, namely physical property and the products subjected to copyrights, were the property of the State Treasury whereas the Unit was only their manager. In the case in question, the property concerned, including physical carriers of audiovisual productions as well as copyrights and related rights to such productions, became the property of the State Treasury. The assets of the liquidated Unit were distributed in two separate ways - one applied to the land, buildings and other devices and premises located on the property of the State Treasury and managed by the Polish Radio and Television on the day the relevant law came into force; and the other - to the remaining assets. By virtue of legal regulations, the former became the subject of perpetual usufruct of newly established companies. In conformity with Art. 65, section 1 of the media act, the Minister of Finance was obliged to transfer the assets remaining after the liquidation of the State Organizational Unit "Polish Radio and Television" to these companies. When the Polish Television company (TVP S.A.) was emerging, the assets of the liquidated unit were neither fully listed nor appraised, which resulted in the dispute over the status of audiovisual archival materials of the public television. This is one of the issues addressed in this paper.
\end{abstract}

Key words: the archival materials of TVP SA, audio-visual works, legal states of archival materials 
